\title{
PERAN TOKOH WANITA PADA MASA KOLONIALISME
}

\author{
Aah Syafaah \\ IAIN Syekh Nurjati Cirebon (aah.syafaah2002@gmail.com)
}

\begin{abstract}
The idea of Shrieke in his race theory, as quoted by Azra, says that the Portuguese expansion can not be separated from the Crusade War in Europe and the Middle East. It is further said that the desire of adventure and ambition of honor combined with religious spirit is the driving force that drives the expansion of the Portuguese into the Asian region. The arrival of the Portuguese came in early 1511 to Malacca, followed by other Europeans such as France, Britain and the Netherlands to various parts of the archipelago, ultimately creating resistance from the people of the archipelago. In an effort to defend his honor and his homeland, the indigenous fighters were not only from the Adam people, as some of them were heroes of the female sex. The colonial period and the effort to achieve independence are very difficult times to pass. Where at that moment, words no longer sounded but only the sounds of ammunition. This is certainly a difficult time especially for women. In this condition, they are required to maintain the honor and salvation of their own lives.
\end{abstract}

Keywords: female, colonial, Islamization

\begin{abstract}
Abstrak
Gagasan Shrieke dalam teori balapannya (race theory), sebagaimana yang dikutip oleh Azra, mengatakan bahwa ekspansi Portugis tidak bisa dilepaskan dari peristiwa Perang Salib (Crusade War) di Eropa dan Timur Tengah. Lebih jauh dikatakan bahwa keinginan berpetualang dan ambisi kehormatan dipadu dengan semangat keagamaan adalah kekuatan pendorong yang menggerakkan ekspansi Bangsa Portugis ke wilayah Asia. Kedatangan Portugis datang pada awal tahun 1511 ke Malaka, yang disusul kemudian oleh bangsa Eropa lainnya seperti Perancis, Inggris, dan Belanda ke berbagai wilayah di Nusantara, pada akhirnya memunculkan perlawanan dari masyarakat Nusantara. Dalam upaya mempertahankan kehormatan dan tanah airnya itu, para pejuang pribumi ternyata tidak hanya berasal dari kaum Adam saja, karena beberapa di antaranya adalah para pahlawan berjenis kelamin wanita. Masa-masa penjajahan dan upaya meraih kemerdekaan merupakan masa-masa yang sangat sulit untuk dilalui. Dimana pada saat itu, kata-kata tidak lagi bersuara melainkan hanyalah suara-suara letupan amunisi. Hal ini tentu menjadi masa sulit terutama bagi kaum wanita. Dalam kondisi ini, mereka dituntut untuk bisa mempertahankan kehormatan dan keselamatan hidup mereka sendiri.
\end{abstract}

Kata Kunci: tokoh wanita, kolonial, Islamisasi.

\section{A. Pendahuluan}

Pertanyaan mendasar yang kemudian timbul dalam ulasan kolonialisme yang kemudian terkait dengan perspektif I'dadul Asykar khususnya yang melibatkan tokoh wanita. Tentu menjadi hal yang sangat menarik untuk diangkat, mengingat selama ini peran tokoh wanita yang ikut serta berjuang dalam proses Islamisasi di masa kolonial justru kurang dikaji.

Sementara itu, agama Islam yang berisi Bahasa dogmatis 
sekaligus etis juga penting untuk dikuliti bagaimana urgensi para wanita untuk ikut serta berjuang baik dalam tataran Islamisasi dan kemerdekaan. Mengingat ada beberapa hadits yang menyebutkan bahwa jihadnya wanita adalah berhaji dan umroh. Tidak ada kewajiban bagi seorang wanita untuk mengambil bagian dalam peperangan kemudian mengangkat senjata melawan penjajahan kaum kolonialis. Hal ini dikutip berdasarkan uraian beberapa hadits di bawah ini:

Dari 'Aisyah ra: aku berkata: "Wahai Rasulullah, apakah perempuan wajib berjihad? Beliau menjawab: "Ya, jihad tanpa ada peperangan di dalamnya yaitu haji dan umroh". Namun adakalanya wanita tidak bisa diabaikan begitu saja dari peranan yang dimilikinya. Hal yang paling memungkinkandalam peperangan-- adalah melalui partisipasi dan keikutsertaan mereka dalam mengobati orang yang terluka dalam peperangan.

Pada hakikatnya, wanita memiliki peran yang multidimensi sekaligus juga melekat dalam dirinya. Dimana ia tidak hanya memiliki peran secara sosial saja tapi juga dalam aspek ekonomi,

\footnotetext{
${ }^{1}$ HR. Ibnu Majah berasal dari Shahih Bukhari.
}

pendidikan, politik, kesehatan dan lainnya. Wilayah peranannya inilah yang menuntutnya untuk memiliki kapasitas untuk melakukan perubahan sekaligus juga gerakan perubahan yang dilakukannya. Terutama selama masa kolonial, keadaan masyarakat berada dalam titik yang sangat lemah, tertindas dan kekurangan akses untuk mendidik dirinya. Bagaimana kemudian dalam hal ini, tokoh wanita mampu menjabarkan dan memetakan peran serta fungsinya untuk menjadi tokoh sentral pembebasan kemerdekaan dalam wilayah geraknya. Tidak hanya menjadi tokoh sekunder yang dikesampingkan jasanya.

Pertanyaan mengenai apa perlunya tokoh wanita untuk mengangkat senjata dalam upaya pembebasan kolonialisme, tentu melahirkan jawaban tersendiri. Mengingat keadaan di Nusantara yang pada saat itu memang sangat kritis dan harus melahirkan gerakan perlawanan untuk mengusir kolonialisme serta melakukan Islamisasi. Hal inilah yang kemudian memberi celah bagi wanita untuk kemudian tidak meninggalkan peranannya dalam kehidupan masyarakat. Terutama yang menyangkut aspek pendidikan yang berorientasi pendidikan. Aspek penting ini jugalah yang tidak pernah ditinggalkan oleh seorang wanita. 
Sepanjang perjalanan historis Islamisasi, wanita sebagai agen pendidik pun kemudian didukung dengan interpretasi hadits berikut:

'Dari Al-Syifa' binti 'Abdullah, Rasulullah saw menemuiku ketika aku sedang berada di rumah Hafshah. Beliau bersabda kepadaku, "mengapa kamu tidak mengajarkan kepada Hafshah sesuatu untuk mengetahui bahwa suatu perkataan tidak berguna dan tidak pula bermanfaat (ruqyah alnamilah) sebagaimana kamu mengajarinya tulis-menulis" (HR. Ahmad dan Abu Dawud).

Dua kepentingan yang dimiliki wanita masa Kolonial yang tidak bisa dilepaskan dari upaya Islamisasi dan perjuangan kemerdekaan, kemudian tidak hanya menuntut kapasitas wanita yang pandai dalam hal edukasi semata. Tapi juga meliputi seluruh aspek terutama yang menyangkut ketahanan fisik. Dimana menurut catatan sejarah Islam, kaum wanita termasuk orang-orang yang ikut serta berhijrah bahkan hingga berperang. Mereka tetap bisa menorehkan prestasi yang mengungguli kaum pria. Karena itulah Islam memandang wanita bukan wanita lemah yang harus disimpan dengan rapi di dalam rumah, tapi ia adalah wanita yang sepantasnya dilindungi, dihargai, diberikan kebebasan untuk membaktikan dirinya bagi lingkungan dan agamanya secara lebih luas, hingga peranan wanita yang tidak hanya mencakup masalah kerumah tanggaan saja tetapijuga mencakup berbagai pendidikan dalam kehidupan di masyarakat.

Konsep inilah yang membuat Islam berbeda dengan prinsip ajaran agama lainnya. Karena Islam tidak membatasi wanita dalam tiga sektor penting yaitu pendidikan, pekerjaan dan politik yang biasa diperjuangkan oleh gerakan kaum feminis yang dituangkan dalam desain-desain perjuangan pembebasan hak wanita melalui penghapusan stereotype, ${ }^{2}$ rasisme, penindasan perempuan dan phalogosentrisme. ${ }^{3}$ Hanya saja, seorang perempuan tetap memiliki peranan dan ciri khas yang berbeda dengan kaum pria. Perbedaan inilah yang kemudian tetap menjadi pakem baginya untuk bergerak di dalam batas kemampuan fitrahnya.

2 Penilaian terhadap seseorang hanya berdasarkan persepsi terhadap kelompok di mana orang tersebut dapat dikategorikan, sumber internet diunduh tanggal 19 November 2017

${ }^{3}$ Ide-ide yang dikuasai oleh logos absolut yaitu laki-laki. Sumber internet diunduh tanggal 19 November 2017 


\section{B. Identifikasi Para Pejuang Wanita Nusantara}

Apa yang terjadi pada masa kolonialisme dan penjajahan, setidaknya menempatkan wanita untuk mau ataupun tidak untuk ikut serta bergerak mengangkat senjata dalam rangka mempertahankan diri, keluarga, agama dan juga negaranya. Hal inilah yang melatarbelakangi perjuangan mereka untuk membebaskan Nusantara sekaligus juga melakukan Islamisasi.

Terdapat banyak nama yang disebutkan sebagai tokoh-tokoh wanita Islam yang ada di Nusantara terutama pada peristiwa Perang Aceh-Belanda dari tahun 1873-1904; seperti Tjut Nyak Dien, ${ }^{4}$ Teungku Fakinah, ${ }^{5}$ Cut Mutia ${ }^{6}$, Pocut Baren, ${ }^{7}$

${ }^{4}$ Ia lahir di Lampadang Kerajaan Aceh pada 1 Januari 1848 dan meninggal di Sumedang pada 6 November 1908 dimakamkan di Gunung Puyuh, sumber internet, diunduh tanggal 19 November 2017

5 Teungku Fakinah adalah seorang ulama wanita besar, seorang pahlawan perang yang ternama dan merupakan pembangun pendidikan ulung yang lahir sekitar tahun 1856 di Desa Lam Diran Kampung Lam Beunot, sumber internet diunduh tanggal 19 November 2017

${ }^{6}$ Cut Mutia (1870-1910) lahir di Kesultanan Aceh. Ia merupakan pahlawan Nasional Indonesia yang dimakamkan di Alue Kurieng Aceh, Sumber internet, diunduh tanggal 19 November 2017

${ }^{7}$ Seorang pahlawan dan ulama dari Aceh yang gigih melawan Belanda. Ia adalah panglima perang dan sebagai uleebalang daerah Gome. Ia mempunyai pengikut setia yang banyak dan membantunya dalam pertempuran melawan
Pocut Meurah $\operatorname{Intan}^{8}$ dan Cutpo Fatimah ${ }^{9}$ hingga Malahayati.

1. Malahayati atau Keumalahayati (15851604)

Malahayati atau Keumalahayati adalah sosok yang lahir era abad ke-16 akhir tepatnya pada tahun 1585-1604 di sebuah wilayah yang dahulu dikenal dengan nama Darud Donya Darussalam (yang dipimpin oleh Sultan Mansyur Syah). Beliau adalah putri dari seorang laksamana yang bernama Mahmud Syah dan disekolahkan di pendidikan militer bahari oleh sang ayah. Keumalahayati memulai kariernya di bidang militer

Belanda. Menurut cerita penduduk ia ikut bergerilya bersama-sama pasukan Cut Nyak Dien, dan setelah Cut Nyak Dien tertangkap, ia tetap meneruskan perjuangan dan menggantikan suaminya yang meninggal dalam peperangan sebagai seorang panglima perang. Sumber internet, diunduh tanggal 19 November 2017

${ }^{8}$ Pocut Meurah Intan adalah puteri keturunan bangsawan dari kesultanan Aceh. Nama Pocut Meurah adalah nama panggilan khusus bagi perempuan keturunan keluarga Sultan Aceh, sumber internet, diunduh tanggal 19 November 2017

${ }^{9}$ Cutpo Fatimah adalah teman seperjuangan Cut Mutia, putri dari seorang ulama besar, Tengku Khatim atau Teungku Chik Mata Ie. Pada pertempuran tanggal 22 Februari 1912 ia dan suaminya Teungku Di Barat syahid bertindih badan, sumber internet diunduh tanggal 19 November 2017 
sebagai prajurit. Kecerdasan dan kemampuannya di bidang tersebut membuatnya menjadi Laksamana wanita pertama di dunia. Selama kariernya, beliau telah berhasil menduduki jabatan sebagai panglima barisan pengawal khusus kerajaan, kemudian menjabat panglima rahasia dan panglima protokol, jabatan terakhirnya yaitu sebagai panglima armada Selat Malaka dan panglima pasukan khusus Inong Balee (laskar/ pasukan perempuan di tanah Rencong).

Kariernya di dunia militer ternyata meletakkannya pada perang-perang melawan portugis dan Belanda. Bahkan Keumalahayati disebutkan pernah membunuh seorang pemimpin pedagang asal Belanda yaitu Cornelis deHoutman ${ }^{10}$ di geladak kapal milik Belanda dalam sebuah perjamuan makan yang disiapkan sebagai jebakan untuk membunuh Laksamana Keumalahayati. Prestasi lain Keumalahayati adalah

10 Cornelis de Houtman adalah seorang penjelajah Belanda yang menemukan jalur pelayaran dari Eropa ke Indonesia dan berhasil memulai perdagangan rempah-rempah bagi Belanda, meninggal di Kesultanan Aceh pada 1 September 1599, sumber internet, diunduh tanggal 19 November 2017 mengkader pasukan perang khusus yang berjumlah 2000 orang yang merupakan pasukan yang terdiri dari janda-janda. Label sebagai grande dame atau wanita yang agung dirasa tidak berlebihan jika disandang oleh Keumalahayati.

2. Kartini dan Rohana Terkait Kartini, Muhammad Abdullah asSyafi' ${ }^{11}$ mempertanyakan tentang mengapa Abendanon memilih Kartini sebagai materi propaganda yang diangkat sebagai tokoh feminisme di Indonesia ini. Sedangkan Rohana yang hidup di zaman yang sama dengan Kartini, dimana akses perempuan untuk mendapatkan pendidikan yang baik sangat dibatasi ini tidak terpilih. Beliau juga mempertanyakan tentang mengapa Kartini yang dipropagandakan di saat Rohana menyebarkan ideidenya secara langsung melalui koran-koran yang diterbitkan sendiri sejak dari Sunting Melayu (Koto Gadang, 1912),

11 Dalam sebuah artikel berjudul "Inilah Wanita-Wanita Nusantara yang Lebih Hebat Daripada Kartini” yang dimuat dalam laman Muslimdaily.net, diakses tanggal 23 Mei 2015. 
Wanita Bergerak (Padang), Radio (Padang), hingga Cahaya Sumatera (Medan).

Rohana lahir di Koto Gadang, Sumatera Barat pada tanggal 20 Desember 1884 dan meninggal di Jakarta pada tanggal 17 Agustus 1972 di usia 87 tahun. Rohana merupakan puteri dari Rasjad Maharaja Soetan dan Ibunya bernama Kiam. Rohana juga merupakan kakak tiri dari Soetan Sjahrir atau yang kita kenal sebagai Perdana Menteri Indonesia yang pertama. Selain itu, Rohana juga adalah seorang bibi atau maktuo dari penyair terkenal yaitu Chairil Anwar sekaligus juga sepupu dari Haji Agus Salim. Latar belakang keluarganya yang rata-rata merupakan tokohtokoh penting dalam sejarah Indonesia rupanya juga ikut menstimulasi semangat Rohana untuk memperjuangkan kemerdekaan khususnya mengangkat derajat, harkat dan martabat kaum wanita Indonesia.

Kesimpulan yang dishahihkan oleh Prof. Harsja W. Bachtiar melalui analisa paparan kedua tokoh tersebut di atas, pada akhirnya menemukan kenyataan bahwa Kartini memang dipilih oleh orang Belanda untuk ditampilkan kedepan sebagai pendekar kemajuan wanita pribumi di Indonesia. Kartini bergaul dengan pasangan suami-istri asisten-Residen Ovink. Kemudian Christiaan Snouck Hurgronje yang merupakan penasehat pemerintah Hindia Belanda ${ }^{12}$

12 Adapun profil Christiaan Snouck Hurgronje (1857-1936) yang lahir tepatnya pada tanggal 8 Februari 1857 di Oosterhout, Holland, selanjutnya pada tahun 1875 ia masuk Universitas Leiden yang pada awalnya mengambil jurusan teologi, kemudian pindah ke Fakultas Sastra Jurusan bahasa Arab. Tahun 1880 meraih gelar doktor dalam Sastra Semit. Kemudian ia mengajar di Leiden pada pendidikan khusus calon pegawai Hindia Belanda dalam mata pelajaran Indologi. Pada tahun 1884 ia pergi ke Jeddah, Saudi Arabia dan kemudian tinggal di Mekah selama 7 bulan dengan nama samaran Abdul Gaffar dan mengaku Islam pada masyarakat Mekah. Tahun 1885 kembali ke Holland mengajar di Leiden. Pada 16 Mei 1889 ia datang ke Batavia, Nusantara dan diangkat sebagai peneliti masalah Islam di Indonesia selama 2 tahun. Pada Maret 1891 diangkat menjadi Penasihat Bahasa Timur dan Hukum Islam oleh pemerintah Belanda. Pada tanggal 9 Juli 1891 berangkat ke Aceh dengan tugas meneliti penduduk Aceh dan Islam dalam situasi Perang Aceh. Tahun 1898-1903 sering pergi ke Aceh dengan tugas meneliti cara menjinakkan Aceh. Pada 11 Januari 1899-1906 diangkat menjadi Penasihat Urusan Pribumi dan Arab di Indonesia (Nederlandsch Indie). Lalu pada tanggal 23 Januari 1907 menerima pengangkatan sebagai Guru Besar merangkap sebagai Penasihat Menteri jajahan Belanda. Syamsu, Ibid, hal. 209-210 
yang mendorong J. $\mathrm{H}$. Abendanon, Direktur Pendidikan, Agama dan Kerajinan agar memberikan perhatian pada Kartini tiga bersaudara. ${ }^{13}$

Prof. Harsja W. Bachtiar dan Tiar Anwar Bachtiar mengungkapkan tentang penokohan Kartini tidak terlepas dari peran Belanda yang melakukan propaganda. Prof. Harsja W. Bachtiar bahkan menyinggung nama $\mathrm{C}$. Snouck Hurgronje yang berperan dalam rangkaian penokohan Kartini oleh Abendanon. Padahal, Snouck Hurgronje adalah seorang orientalis Barat. Dalam hal ini, pakar sejarah Melayu yaitu Prof. Naquib al-Attas mengingatkan kita tentang adanya upaya yang sistematis dari orientalis Belanda untuk memperkecil peran Islam dalam sejarah Kepulauan Nusantara.

13 Harsja menuliskan kisah ini berupa: "Abendanon mengunjungi mereka dan kemudian menjadi semacam sponsor bagi Kartini. Kartini berkenalan dengan Hilda de Booy-Boissevain, istri ajudan Gubernur Jenderal, pada suatu resepsi di Istana Bogor, suatu pertemuan yang sangat mengesankan kedua belah pihak", dalam artikel "Inilah Wanita-Wanita Nusantara yang Lebih Hebat Daripada Kartini" yang dimuat dalam laman Muslimdaily.net, diakses tanggal 23 Mei 2015.
Kembali kepada ulasan mengenai Rohana yang aktif berkiprah di tengah masyarakat, Rohana tetap memiliki visi keislaman yang tegas yang tercermin dalam pernyataan tegasnya. ${ }^{14}$ Akan tetapi, gaung mengenai Rohana Kudus mungkin masih tidak sehebat Kartini yang hadir dengan idenya yaitu "Habis Gelap Terbitlah Terang”. Hal yang menjadi unik adalah ketika latar belakang slogan "Habis Gelap Terbitlah Terang" tersebut kemudian menjadi sebuah buku dengan judul yang sama tersebut adalah berupa kenyataan bahwa Kartini muda terinspirasi dari salah satu kutipan Al-Qur'an, tepatnya Surat An-Nur 35. ${ }^{15}$

14 "Perputaran zaman tidak akan pernah membuat wanita menyamai laki-laki. Wanita tetaplah wanita dengan segala kemampuan dan kewajibannya. Yang harus berubah adalah wanita harus mendapat pendidikan dan perlakuan yang lebih baik. Wanita harus sehat jasmani dan rohani, berakhlak dan berbudi pekerti luhur, taat beribadah yang kesemuanya hanya akan terpenuhi dengan mempunyai ilmu pengetahuan", (kutipan Rohana Kudus dalam artikel berjudul "Inilah Wanita-Wanita Nusantara yang Lebih Hebat Daripada Kartini" yang dimuat dalam laman Muslimdaily.net, diakses tanggal 23 Mei 2015).

15 Artinya: Allah (pemberi) cahaya (kepada) langit dan bumi. Perumpamaan cahaya-Nya seperti sebuah lubang yang tidak tembus (misykat) yaitu suatu lubang di dinding rumah 
3. Sultanah Sri Ratu Tajul Alam Safiatuddin Johan (1641-1675)

Selain tentang Kartini dan Rohana, Prof. Harsja W. Bachtiar menyumbangkan dua nama tokoh wanita dalam pergerakan nasional Indonesia. Kedua nama tersebut adalah Sultanah Sri Ratu Tajul Alam Safiatuddin Johan yang memiliki kedaulatan di Aceh dan Siti Aisyah We Tenriolle dari Sulawesi Selatan. ${ }^{16}$ Meskipun menurutnya, kedua

yang tidak tembus sampai ke sebelahnya, biasanya digunakan untuk tempat lampu atau barang-barang lain. Yang dibalamnya ada pelita besar. Pelita itu di dalam tabung kaca (dan) tabung kaca itu bagaikan bintang yang berkilauan, yang dinyalakan dengan minyak dari pohon yang diberkahi (yaitu) pohon zaitun yang tumbuh tidak di timur dan tidak pula di barat, yang minyaknya (saja) hampir-hampir menerangi, walaupun tidak disentuh api. Cahaya di atas cahaya (berlapis-lapis), Allah memberi petunjuk kepada cahaya-Nya bagi orang yang Dia kehendaki, dan Allah membuat perumpamaan-perumpamaan bagi manusia. Dan Allah Maha Mengetahui segala sesuatu.

16 Ia adalah Datu (Ratu) tokoh emansipasi wanita dari Bugis, tepatnya di Tanete Sulawesi Selatan. Dia menguasai kerajjaan Tanete dan Bugis. Kontribusinya lainnya adalah mampu menterjemahkan mahakarya epos La Galigo yang berbahasa Bugis kuno ke dalam Bahasa Bugis umum sehingga ia mendapatkan popularitas hingga samudra dan benua Eropa. Meskipun tahun kelahirannya tidak diketahui namun ia meninggal pada tahun 1919 Pancana Tanette ri Lau yang merupakan kampong kelahirannya, sumber internet, diunduh tanggal 19 November 2017 nama ini tidak masuk kedalam buku sejarah Setengah Abad Pergerakan Wanita Indonesia terbitan Kongres Wanita Indonesia atau akronimnya Kowani tahun 1978. Menurutnya, kedua nama ini memiliki kehebatan yang sangat luar biasa.

Sultanah Safiatuddin dikenal sebagai sosok yang sangat pintar dan aktif mengembangkan ilmu pengetahuan. Ia merupakan seorang sultanah atau ratu yang memerintah antara tahun 16411675. Sebelum ia menjadi seorang sultanah, Aceh dipimpin oleh suaminya yaitu Sultan Iskandar Tsani (16371641). Setelah Iskandar Tsani wafat amatlah sulit mencari pengganti laki-laki yang masih berhubungan keluarga dekat. Terjadi kericuhan dalam mencari penggantinya, kaum ulama dan wujudiah $^{17}$ tidak menyetujui jika perempuan menjadi raja dengan alasanalasan tertentu. Kemudian seorang ulama besar bernama

${ }^{17}$ Golongan sufisme-filosofis yaitu orang yang lebih mempelajari seluk beluk sufisme dan kalam daripada syari'at, terutama pada abad ke17. Azra, Ibid, hal. 118 
Nurudin

Ar-Raniri ${ }^{18}$

menengahi kericuhan tersebut dengan menolak argumenargumen kaum ulama. Sehingga Sultanah Safiatuddin diangkat menjadi sultanah (Ratu).

\section{Sultanah Safiatuddin}

menceritakan bahwa ia gemar mengarang sajak dan cerita serta membantu berdirinya perpustakaan di negerinya. Selain menguasai bahasa Aceh dan Melayu, dia menguasai bahasa Arab, Persia, Spanyol dan Urdu. Di masa pemerintahannya, ilmu dan kesusasteraan berkembang pesat. Ketika itulah lahir karya-karya besar dari Nuruddin ar-Raniry, Hamzah Fansuri ${ }^{19}$ dan Abdur Rauf al-

18 Nuruddin ar-Raniry atau yang bernama lengkap Nuruddin Muhammad bin Ali bin Hasanji bin Muhammad Hamid ar-Raniry alQurasyi asy-Syafi'i merupakan seorang ulama terkenal yang menghasilkan banyak buku besar yang besar pengaruhnya bagi rakyat Aceh. Ia adalah seorang sarjana asal India yang memiliki keturunan Arab. Ia belajar agama dari daerahnya sendiri di Ranir, Gujarat, India. Kemudian ia melanjutkan pelajaran ke Tarim, Hadramaut, Arab Selatan yang ketika itu merupakan pusat studi agama Islam. pada tahun 1030 H (1621 M) Ia menuju ke Mekah dan Madinah. Sumber dari buku Ulama Pembawa Islam di Indonesia dan Sekitarnya, hal. 9-10.

19 Al-Fansuri adalah seorang sufi pengembara yang mengunjungi pusat-pusat keilmuan dan pengajaran Islam yang penting di Timur Tengah termasuk Makkah, Madinah, Jerusalem, dan
Sinkili. ${ }^{20}$ Ia juga berhasil menampik usaha-usaha Belanda untuk menempatkan diri di daerah Aceh. Sehingga VOC tidak memiliki kesempatan untuk memonopoli atas perdagangan timah dan komoditi lainnya. Ia dikenal sangat memajukan pendidikan, baik untuk pria maupun untuk wanita.

Selama 35 tahun memerintah (1051-1086 H/1641-1675 M), Sultanah Safiatuddin juga membentuk barisan perempuan pengawal istana yang turut berperang dalam Perang Malaka tahun 1639. Ia juga meneruskan tradisi pemberian tanah kepada pahlawan-pahlawan perang sebagai hadiah dari kerajaan. Selama masa pemerintahannya, ia menegakkan syariat Islam.

Baghdad. Di Baghdad inilah dia memasuki tarikat Qadiriyah sebelum akhirnya dia kembali ke Aceh. Azra, Islam Nusantara, hal. 119

${ }^{20}$ Abd Al-Ra'uf Al-Jawi Al-Fansuri Al-Sinkili (1024-1105 H/1615-1693 M) lahir di Singkel, sebelah utara Fansur di pantai barat Aceh. Dia sampai ke Timur Tengah pada sekitar 1051 H/1640 M sampai wafatnya gurunya, Ahmad Al-Qusyasyi pada tahun $1071 \mathrm{H} / 1661 \mathrm{M}$ Sepeninggal gurunya dia kembali ke Aceh sampai wafatnya. Dia mendapatkan jabatan sebagai Mufti Kesultanan Aceh dari Sultanah Safiatuddin (1051-1086 H/1641-1675 M). Azra, Ibid, hal. 104 
Atas permintaannya, Nuruddin ar-Raniry menulis buku berjudul Hidayatul Imam yang ditujukan bagi kepentingan rakyat umum. Sementara Abdur Rauf Singkil menulis buku berjudul Mir'at alThullab fi Tasyil Mawa'iz alBadi'rifat al-Ahkam alSyar'iyyah li Malik al$W_{a h h a b^{21}}$ untuk dijadikan pedoman bagi para qadhi dalam menjalankan tugas pemerintahannya sesuai dengan hukum Islam.

4. Siti Aisyah We Tenriolle

Menurut Prof. Harsja W. Bachtiar adalah Siti Aisyah We Tenriolle. Wanita ini bukan hanya dikenal dalam pemerintahan tetapi juga mahir dalam kesusasteraan. B.F. Matthes yang merupakan seorang ahli sejarah Sulawesi Selatan yang berasal dari Belanda mengaku mendapat manfaat besar dari sebuah epos La-Galigo yang mencakup lebih dari tujuh ribu halaman folio. Ikhtisar epos besar itu dibuat sendiri oleh We Tenriolle.

${ }^{21}$ Selain, 'Umdat al-Muhtajin; sebuah catatan perjalanan menuntut ilmu yang merupakan karangannya sendiri untuk membuktikan kualifikasinya (bona fides) sebagai guru agama saat itu. Azra, Ibid., hal.104-106
Meminjam perspektif Tiar Anwar Bahtiar $^{22}$ yang menyebutkan tentang sejumlah sosok wanita yang sangat layak dimunculkan seperti Dewi Sartika di Bandung dan Rohana Kudus di Padang (kemudian pindah di Medan). ${ }^{23}$ Menurutnya, Dewi Sartika (1884-1947) bukan hanya berwacana tentang pendidikan kaum wanita, tapi juga berhasil mendirikan sekolah yang dinamakan Sakola Kautamaan Istri (1910) yang berdiri di beberapa tempat baik di dalam maupun luar Bandung. Sedangkan Rohana Kudus (1884-1972) melakukan hal yang sama di kampung halamannya. Selain mendirikan Sekolah Kerajinan Amal Setia (1911) dan Rohana School (1916), Rohana Kudus bahkan menjadi jurnalis sejak di Kota Gadang sampai saat ia mengungsi ke Medan. Rohana Kudus tercatat sebagai jurnalis wanita pertama sekaligus pendiri surat kabar perempuan pertama di Indonesia. 
5. Tokoh-tokoh Wanita di Cirebon

Jika kita mengenal beberapa teori Islamisasi dalam kajian sejarah pada masa awal sebelum kedatangan kolonial, makadalam kajian ini kita hanya akan secara khusus mengenai teori sekaligus implikasi Islamisasi yang lebih massif dilakukan melalui pernikahan,sebagaimana yang dilakukan oleh Sunan Gunung Jati. Adapun beberapa nama tokoh wanita yang penting dan dinikahi oleh Sunan Gunung Jati di antaranya adalah sebagai berikut:

a. Nyi Mas Ratu Kawunganten

Pernikahan ini terjadi pada tahun 1475, setelah terlebih dahulu mengislamkan Adipati Kawunganten dan pengikutnya. Dari perkawinan ini, lahirlah Ratu Winaon dan Pangeran Sebakingkin yang kelak dinobatkan sebagai Adipati Banten dengan gelar Pangeran Maulana Hasanuddin pada tahun 1525 .

b. Syarifah Quraisin atau Nyi Mas Rara Bagdad
Pernikahan Sunan Gunung Jati dengan Nyi Mas rara Bagdad ini melahirkan dua orang putra yang diberi nama Pangeran Jayalelana dan Pangeran Bratalelana. Pangeran Jayalelana gemar berkelana dan memberikan

pengobatan kepada masyarakat pedesaan dan dikenal dengan julukan Ki Gede Lemah Tamba. Pangeran Jayalelana akhirnya menetap di pesisir utara Cirebon sebagai Ki Gede Mertasinga.

Sedangkan Pangeran Bratalelana yang semula tinggal di Demak sebagai menantu Sultan Demak, akhirnya meninggal dunia saat akan kembali pulang ke Cirebon. Ia meninggal dalam pertempuran dengan perompak dalam pelayaran dari Jepara ke Cirebon. Kematiannya itulah yang kemudian membuat masyarakat 
menyebutnya dengan nama Pangeran Seda Ing Lautan atau Pangeran yang meninggal di tengah laut.

c. Nyi Mas Tepasari

Saat Sunan Gunung Jati berdakwah di daerah Tepasan (sekarang dikenal dengan daerah Bumiayu, Brebes). Di sana beliau mengislamkan Adipati Tepasan yang merupakan seorang sentana Majapahit yang sekaligus juga berperan sebagai penguasa daerah setempat. Sunan Gunung Jati pun kemudian menikahi putri sang Adipati yang bernama Nyi Mas Tepasari pada tahun 1471. Dari perkawinan tersebut lahirlah duan orang anak, yaitu Ratu Wulung Ayu (kelak Ratu Wulung Ayu menikah dengan Pangeran Sebrang Lor atau Adipati Yunus dari Demak. Setelah Yunus wafat, Ratu Wulung Ayu menikah lagi dengan Fadhilah Khan, seorang Panglima Demak asal Pasai, Aceh) dan Pangeran Muhammad Arifin atau Pangeran Pasarean.

d. Ratu Pakungwati

Sunan Gunung Jati menikahi saudara sepupunya yang merupakan putri dari uwaknya yaitu $\mathrm{Ki}$ Kuwu Cerbon

Cakrabuwana.

Sepupunya yang bernama Ratu Pakungwati itu dinikahi pada tahun 1478 , tanpa memiliki keturunan. Setelah madunya, Ratu Mas Tepasari wafat dengan meninggalkan dua orang anak, Ratu Pakungwati mengambil alih pengasuhan atas kedua anak tirinya, Ratu Wulung Ayu dan Pangeran Muhammad Arifin (Pangeran Pasarean). Ratu Pakungwati wafat pada waktu terjadi peristiwa pageblug Menjangan Wulung di Mesjid Agung Sang Cipta Rasa, Cirebon. 
Dari keempat istri Sunan Gunung Jati, peran para istri tersebut begitu nyata dalam membantu pelaksanaan dakwah yang dilakukan oleh Sunan Gunung Jati. Bahkan tidak hanya sebatas membantu, tetapi juga dengan melahirkan para keturunan yang kelak akan melanjutkan proses islamisasi pada masa berikutnya.

\section{Penutup}

Kartini bukan satu-satunya tokoh wanita dalam historisitas sejarah Nusantara. Keberpihakan orientalis dalam hal ini adalah Snouck tidak bisa dinafikan begitu saja karena saat menokohkan Kartini sebagai pejuang emansipasi wanita di Nusantara memang tidak bisa dilepaskan dari pergaulan seorang kartini dengan Abendanon. Apalagi pada saat itu, Snouck juga merupakan penasehat Belanda bagi masyarakat pribumi Indonesia, seorang Adviseur (penasehat) Gubernur Jenderal Belanda bagi masyarakat di Hindia-Belanda.

Lebih jauh wanita-wanita kuat dapat diperoleh melalui jalur pernikahan—salah satunya-- dalam saluran islamisasi yang terjadi di Nusantara, khususnya di wilayah Cirebon sebagaimana dipaparkan di atas, telah membuka wacana baru terkait peran wanita-wanita hebat-yang turut membantu proses dakwah Sunan Gunung Jati dalam mengislamkan masyarakat Cirebon dan sekitarnya-- yang tidak hanya sebatas lingkup domestik tetapi juga di ranah publik. Wallahu a'lam.

\section{Daftar Pustaka}

Azyumardi Azra.Islam Nusantara Jaringan Global dan Lokal. Bandung: Mizan. 2002.
Thomas Stamford Raffles.The History of Java. Yogyakarta: Narasi. 2014.

Muhammad Syamsu As. Ulama Pembawa Islam di Indonesia dan Sekitarnya. 1999.

Hamid al-Gadri. C. Snouck Hurgronje, Politik Belanda terhadap Islam dan Keturunan Arab. Jakarta: Sinar Harapan. 1984.

A. Sobana Hardjasaputra (Ed.). Cirebon dalam Lima Zaman. Bandung: Dinas Pariwisata dan Kebudayaan Propinsi Jawa Barat. 2011. 
L.W.C. Van den Berg. Orang Arab di Nusantara. Depok: Komunitas Bambu. 1989.

Anthony Reid. Asia Tenggara dalam Kurun Niaga 1450-1680. (Terj.) Jakarta: Yayasan Obor Indonesia. 2011.

Musrifah Sunanto, Sejarah Peradaban Islam Indonesia, Jakarta: Raja Grafindo Persada, 2005.

M. Naquib al-Attas, Historical Fact and Fiction, hal. xvi, dalam "Islam Nusantara: Islamisasi Nusantara atau Menusantarakan Islam?", artikel, A. Kholili Hasib (Pengurus Majelis Intelektual dan Ulama Muda Indonesia/MIUMI)
Jawa Timur, dimuat dalam Muslimdaily.net, diakses tanggal 25 Mei 2015

\section{Sumber Internet:}

Harsja W. Bachtiar.Inilah WanitaWanita Nusantara yang Lebih Hebat Daripada Kartini.

Muslimdaily.net.Diakses tanggal 23 Mei 2015.

Jurnal Islamia dalam Insists. Republika tanggal 9 April 2009

Wikipedia. com 